DOI:10.17951/h.2019.53.1.99-109

\begin{tabular}{lc}
\hline & A N N A L E S \\
UNIVERSITATIS MARIAE CURIE-SKŁODOWSKA \\
LUBLIN - POLONIA \\
SOL. LIII, 1 & SECTIO H \\
\hline
\end{tabular}

DAWID SZOSTEK

dawidsz@umk.pl

Nicolaus Copernicus University in Torun,

Faculty of Economic Sciences and Management, Gagarina 13a, 87-100 Toruń, Poland

ORCID ID: https://orcid.org/0000-0001-6743-854X

\title{
Activities of organizations located in Poland in the field of sustainable development
}

Keywords: sustainable development; sustainable management

JEL: Q010; Q560

How to quote this paper: Szostek, D. (2019). Activities of organizations located in Poland in the field of sustainable development. Annales Universitatis Mariae Curie-Skłodowska, sectio H-Oeconomia, Vol. 53, No. 1.

\footnotetext{
Abstract

Theoretical background: The article discusses the activities of organizations located in Poland in the field of sustainable development (SD). This is a specific development, which considers the needs of future generations. These activities may concern environmental, social or economic issues. The identified knowledge gap refers to the type of the most common SD-activities, possible partners in such projects, employee involvement and motivation to participate in such activities, and the perceived advantages and negative aspects of SD-projects.

Purpose of the article: The purpose of the article is to evaluate the activities of organizations located in Poland in the field of sustainable development. The described issues include: the type of the most common SD-activities, possible partners in such projects, employee involvement and motivation to participate in such activities, and the perceived advantages and negative aspects of SD-projects.

Research methods: The empirical material was obtained from 13 individual in-depth interviews conducted by telephone in 2018 .

Main findings: The analysed organizations implemented mainly social, but also ecological projects. By the implementation of projects, they cooperated mainly with NGO-partners, but only if it was necessary (e.g. if the NGO had more knowledge and experience in a specific field). Most of the projects were based on the
} 
active participation of employees in the form of volunteering; such projects had the most positive effects for the project's goals, but also for the employees and the company. Hence, companies willingly motivated employees to participate in such projects not only by informational and organizational support, but also through various methods of distinguishing employees (e.g. volunteering gala, cup of coffee with the CEO). Companies see considerable benefits in such projects for themselves and for the staff. The perceived disadvantages are few, and in any case they can be minimized and are fully discounted by the potential benefits.

\section{Introduction}

Nowadays there are an increasing number of publications relating to sustainable development (SD), as becomes clear when entering keywords such as "sustainable development" or "sustainable management" in a browser. Unfortunately, the sources do not provide an exhaustive answer to the question of why and in what manner an organization should engage in the activities (Kumar \& Rahman, 2015, p. 110). There are numerous information gaps in the literature, including those relating to the following:

1) What activities are undertaken most often? Are these activities undertaken independently or in cooperation with others?

2) Do employees take an active part in the activities and how are they motivated to do so?

3) What are the advantages and disadvantages connected with the activities?

The described gap applies, to a greater extent, to literature in Polish, which results from insufficient research in Poland. Therefore, this article's purpose is to evaluate the activities in the field of SD as undertaken by organizations located in Poland. The aim will be accomplished through the analysis of data obtained from 13 non-standardized individual in-depth interviews (IDI) conducted by telephone in 2018 .

\section{Literature review}

The definition of SD appeared for the first time in the report of the World Commission on Environment and Development (United Nations) in 1987. It refers to a development that "makes it possible to satisfy current demands without a fear that demands of future generations will not be satisfied" (Brundtland, 1987, p. 41). This development should be realized voluntarily and inherently in three aspects: environmental, social and economic (Carter \& Rogers, 2008; Kumar \& Rahman, 2015). The implementation of SD in practice means that material, information and capital flows are realized in consideration of the objectives of all the above-mentioned three aspects of SD (Seuring \& Müller, 2008, p. 1700).

Table 1 includes a list of activities which indicate whether an organization realizes SD. 
Pobrane z czasopisma Annales H - Oeconomia http://oeconomia.annales.umcs.pl Data: 26/04/2023 11:36:43

ACTIVITIES OF ORGANIZATIONS LOCATED IN POLAND...

Table 1. Areas and indicators of sustainable development in an organization

\begin{tabular}{|l|l|}
\hline \multicolumn{1}{|c|}{ Area } & \multicolumn{1}{c|}{ Indicators } \\
\hline Environmental & $\begin{array}{l}\text { Improvement of packaging, energy efficiency, decrease in pollution emissions, minimization } \\
\text { of waste, reverse logistics*, green purchasing (i.e. purchase of ecological products), green } \\
\text { designing (environment-friendly facilities/systems), substitution of materials, ecological } \\
\text { marking, use of renewable energy and clean technologies }\end{array}$ \\
\hline Social & $\begin{array}{l}\text { Conditions of work, employees' rights, fair trade, transparency, education of employees, } \\
\text { career development, work-life balance, social welfare, fair remuneration, safety, health, } \\
\text { adjustment of work to specific needs of employees, purchased in local markets, poverty } \\
\text { reduction, supplies from less developed social strata, support of communities, guaranteeing } \\
\text { of work in the local markets, codes of ethics, equal treatment }\end{array}$ \\
\hline Economic & $\begin{array}{l}\text { Optimization of resources, reduction of raw materials, reduction of costs, delaying deliver- } \\
\text { ies, minimization of shortages }\end{array}$ \\
\hline
\end{tabular}

* Reverse logistics involves the management of flows of waste and damaged products (from manufacturing sites to destination places) in order to regain their value (repair, recycling or processing) or proper storage in order to ensure the economic efficiency of the processes and the minimization of negative influence upon the natural environment (Szołtysek, 2009, p. 80).

Source: Author's own study based on (Kumar \& Rahman, 2015, pp. 113-115).

The main reasons for the involvement of an organization in SD are the potential advantages stemming from it. The most oft-mentioned advantages include competitive advantage, an opportunity to apply higher prices, the growth of product quality, improvement of the image/reputation, reduction of costs, optimization of activities, new market opportunities, improvement of the value for customers, growth of stakeholder satisfaction, improvement of profitability and reduction of losses (Kumar \& Rahman, 2015, p. 116).

However, an organization may encounter numerous obstacles as regards such activities, including high conversion costs, an excessive focus on current profits, the absence of resources (including funds), the insufficient level of integration of an organization, the absence of governmental support, the resistance of partners and their limited involvement, the insufficient support of the management board, cultural differences, insufficient awareness, knowledge and training, organizational standards, and failure to share knowledge and technology (Kumar \& Rahman, 2015, p. 117). It should be noted that one of the greatest obstacles is the internal resistance of employees or their failure to be involved to a sufficient extent (Florida, 1996, p. 92, 96; Wu \& Pagell, 2011, p. 583).

Employees' attitudes are very significant for such activities to be successful. It is only the voluntary activities of an organization in the field of SD that can contribute positively to the involvement of employees (Wolf, 2013, p. 93; Verhulst \& Boks, 2014, p. 75; Galpin et al., 2015, p. 9; Godkin, 2015, p. 15; Temminck, 2015, p. 402, 404; Polman \& Bhattacharya, 2016, p. 38), and, simultaneously, to the sustainable functioning of an organization (Ji et al., 2012, p. 2998; Cirnu \& Kuralt, 2013, pp. 2-4; Temminck, 2015, p. 404; Polman \& Bhattacharya, 2016, p. 36). This is because employees trust their employers only when they perceive their activities to be sincere (Christian et al., 2011, p. 99). It is also worth emphasizing that an organization is perceived as being 
managed in a sustainable manner when its activities focus on environmental and social issues. The prevalence of economic aspects leads to an increase of scepticism for employees (Cirnu \& Kuralt, 2013, p. 9; Polman \& Bhattacharya, 2016, p. 36).

Employees' willingness to be involved in SD also depends on the example set by employers (Ji et al., 2012, p. 2998; Godkin, 2015, p. 17). Furthermore, the involvement may be intensified by training, which leads to changes in attitudes and an increase in motivation (Ji et al., 2012, p. 2999; Wolf, 2013, p. 97; Liu, 2014, p. 196; Verhulst \& Boks, 2014, p. 73). One should also develop conditions of work in order to facilitate the employee's involvement in SD (Temminck, 2015, p. 408; Polman \& Bhattacharya, 2016, p. 37).

\section{Research methodology ${ }^{1}$}

Organizations to be subject to the research were selected based on the available rankings of Corporate Social Responsibility (CSR). A search was conducted mostly for organizations which realize such activities with the active participation of employees and, furthermore, in cooperation with other entities (e.g. NGOs, enterprises). From among 72 selected organizations, the data of 13 organizations are presented, which expressed their consent to participate in IDIs. Eight are large enterprises (industries: finance -3 organizations, finance -1 , production of machinery and equipment -2 , production of building materials -1 , production of food -1 ) and 5 are corporate funds (created by the corporation and controlled by the same). As many as 12 organizations are Polish divisions of international corporations. Telephone interviews were conducted among employees responsible for CSR in May and June 2018 with the use of the scenario. The respondents were selected arbitrarily by the companies. The collected material was subject to transcription and encoding (independently by 3 persons) and analysis in MAXQDA application. Table 2 includes a list of codes discussed in the paper.

Table 2. Codes discussed in the paper

\begin{tabular}{|c|c|}
\hline Code & Code description \\
\hline \multicolumn{2}{|r|}{ Codes relating to realized projects } \\
\hline PROBLEMS & $\begin{array}{l}\text { What types of problems do the projects solve? Are these ecological, social or other } \\
\text { problems? What are the contents of such projects and who are their beneficiaries? }\end{array}$ \\
\hline PROFILE & Are the projects connected/not connected with an organization profile? \\
\hline REASONS & Why does an organization undertake to realize such projects? \\
\hline COOPERATION & $\begin{array}{l}\text { Does an organization realize such projects by itself or in cooperation with others? } \\
\text { (or, possibly, what is the share of cooperation and what entities does an organization } \\
\text { cooperate with?) }\end{array}$ \\
\hline
\end{tabular}

1 The project was funded by the National Science Centre, Poland, on the decision number DEC2017/25/B/HS4/01113. The research team are employees of the Faculty of Economic Sciences and Management at the Nicolaus Copernicus University in Torun (i.e. Aldona Glińska-Neweś, Justyna Łapińska, Iwona Eescher, Barbara Józefowicz, Joanna Petrykowska, Dawid Szostek, Paweł Brzustewicz). 
Pobrane z czasopisma Annales H - Oeconomia http://oeconomia.annales.umcs.pl

Data: 26/04/2023 11:36:43

ACTIVITIES OF ORGANIZATIONS LOCATED IN POLAND...

\begin{tabular}{|c|c|}
\hline Code & Code description \\
\hline $\begin{array}{l}\text { PROJECTS - } \\
\text { ADVANTAGES }\end{array}$ & $\begin{array}{l}\text { What are the advantages for an organization resulting from the realization of such } \\
\text { projects? }\end{array}$ \\
\hline $\begin{array}{l}\text { PROJECTS - } \\
\text { DISADVANTAGES }\end{array}$ & What are the negative effects of such projects that an organization can see for itself? \\
\hline & Codes relating to cooperation in realized projects \\
\hline DURABILITY & Is cooperation of the parties for realization of the projects $\mathrm{p}$ \\
\hline FORMALIZATION & formalized or non-formalized? \\
\hline $\begin{array}{l}\text { COOPERATION } \\
\text { INITIATIVE }\end{array}$ & $\begin{array}{l}\text { Does cooperation result from personal contacts between representatives of the parties } \\
\text { or from other reason? }\end{array}$ \\
\hline $\begin{array}{l}\text { COOPERATION - } \\
\text { ADVANTAGES } \\
\end{array}$ & $\begin{array}{l}\text { tages of cooperation can an organization see for itself? Would the advan- } \\
\text { erent, if a project was realized by an organization on its own? }\end{array}$ \\
\hline $\begin{array}{l}\text { COOPERATION - } \\
\text { DISADVANTAGES }\end{array}$ & $\begin{array}{l}\text { What negative effects of cooperation can an organization see for itsel } \\
\text { negative effects be different, if a project was realized by an organizati }\end{array}$ \\
\hline \multicolumn{2}{|r|}{ Codes relating to the active participation of employees in realized projects } \\
\hline ACTIVE & $\begin{array}{l}\text { Do the projects involve the active participation of employees or not? (or possibly, } \\
\text { what is the active share of employees?) }\end{array}$ \\
\hline ORGANIZATION & $\begin{array}{l}\text { How is the project organized (particular activities)? Is employees' involvement for- } \\
\text { malized or not? Is it permanent or temporary? Do employees participate in the project } \\
\text { during working hours or outside work? Are they paid or not? }\end{array}$ \\
\hline INNER INITIATIVE & $\begin{array}{l}\text { Where did the idea of the project originate from? (suggested by the executive staff or } \\
\text { employees?) Does it result from relations between employees and beneficiaries? }\end{array}$ \\
\hline MOTIVATING & $\begin{array}{l}\text { Are employees encouraged to take an active part in the project? If yes, how are they } \\
\text { encouraged? }\end{array}$ \\
\hline \begin{tabular}{l|} 
DEVELOPMENT OF \\
COMPETENCES
\end{tabular} & $\begin{array}{l}\text { Does an organization develop employees' competences necessary for participation in } \\
\text { the realization of the projects? If yes, how? }\end{array}$ \\
\hline
\end{tabular}

Source: Author's own study.

\section{Discussion of the research results}

\section{PROBLEMS}

The realized projects were mostly social projects, such as:

- scholarships for the disabled;

- collecting of items and funds (e.g. for children from orphanages, poor families);

- educational activities (e.g. relating to traffic safety, management of one's own funds, preparation of $\mathrm{CVs}$ );

- spending time together with the needy;

- creating meeting rooms for relatives and children in hospitals, renovation of day rooms,

- charity runs.

Ecology-related projects include:

- planting of trees, air protection (e.g. promotion of moving around without vehicles);

- sowing grasslands in cities;

- revitalization of parks, squares, etc. 


\section{PROFILE}

To the question of whether projects relating to SD comply with the profile of activities of an organization, only 1 respondent answered "yes", while 4 answered "no", 6 - "sometimes" and 2 did not provide any answer.

\section{REASONS}

All reasons can generally be divided into:

a) utilitarian:

- willingness to share the potential of an organization with its environment and conduct a dialogue;

- realization of assumptions of the strategy of CSR, the development of socially- and ecologically-oriented organizational culture;

- building of ecological and social awareness among employees or other stakeholders;

b) pragmatic:

- building of an image of a socially responsible organization and good employer;

- realization of recommendations of a new owner;

- development of employees to become ambassadors of an organization;

- giving employees an opportunity to participate in such projects as a method of achieving a balance between life and work;

- increasing commitment of staff to work.

\section{COOPERATION}

Realizing projects, all organizations cooperate with other entities, if this is necessary. They mainly cooperate with organizations with greater experience in the field to which a project relates, e.g.:

- NGO: an organization specializing in crowdfunding, grant projects, scholarships for young people, sowing of urban grasslands, working voluntary activities, police, a territorial local government unit;

- commercial entities: an enterprise specializing in fighting smog, advertising agency, supermarket chain.

Frequently, a cooperating organization is a corporate fund (created by an enterprise and controlled by the same). Employees of the fund often include seconded employees of the enterprise.

\section{PROJECTS - ADVANTAGES}

Advantages can generally be divided into those:

a) for an organization:

- improvement of the image of an organization within and outside;

- improvement of communication with the external world;

- increase of business reliability;

- attracting better potential employees; 
- increase of commitment of staff to work;

- building of relations with the external world;

b) for staff:

- increase of employee satisfaction, their trust in their own abilities and loyalty towards the employer;

- better integration of employees and improvement of relations between them;

- improvement of the atmosphere at work;

- increase of balance between work and private life;

- taking care of the development of staff;

- better self-presentation of employees and an increase in their public presentation skills;

- improvement of qualifications of employees in the field of project, crisis and team management and negotiations;

- advantages for the direct environment of employees (e.g. teaching children how to be altruistic).

\section{PROJECTS - DISADVANTAGES}

Most organizations thought that the SD activities did not cause any losses. However, they indicated some drawbacks, namely:

- large involvement in the project may lead to delays at work;

- an employee's physical burden as regards contacts with deprived beneficiaries (e.g. sick children);

- difficulties in struggling with the passiveness of an organization - beneficiary;

- accompanying negative emotions may contribute to the worsening of the image of the employer;

- certain projects may have a bad reception in a given area (e.g. anti-smog activities in the Silesia).

\section{DURABILITY}

There was only 1 organization which indicated that cooperation with another entity has a permanent character; 3 stated that it had a temporary character and 9 did not provide any information.

\section{FORMALIZATION}

In 4 cases, cooperation between organizations was not formalized (by way of an agreement) and in 1 case it applied to some entities. No information was obtained from 4 organizations.

\section{COOPERATION INITIATIVE}

Most often it was an organization itself that came up with the cooperation initiative (7 indications), however, it was also an external entity (4). In rarer cases, 
employees were sources of the initiative (1) or personal relations between the employees and employees of external entities (3).

\section{COOPERATION - ADVANTAGES}

The organizations indicated that advantages stemming from the cooperation were similar to those obtained as a result of the independent realization of the project; apart from that, it is difficult to differentiate between the advantages, as cooperation is always reasonably justified. The following were indicated as added values of the cooperation:

- relations that are created with an external entity;

- greater involvement of employees in projects and work;

- greater advantages for the image of an organization;

- an opportunity to derive benefit from a partner's knowledge and experience.

\section{COOPERATION - DISADVANTAGES}

Drawbacks of the projects realized in cooperation are similar to those realized independently. Additionally, one may distinguish between the following:

- the need to reconcile the work of different entities;

- external entities are often passive, and await an initiative and greater financial involvement on the part of a leader;

- smaller organizations work much more slowly than large corporations;

- additional costs resulting from ordering some activities from an external entity.

\section{ACTIVE}

The organizations realized projects based upon the active involvement of employees (e.g. conducting of educational classes, planting of trees, cleaning of squares, collections) or without their involvement (e.g. funding of scholarships for poor children, preparation of anti-smog reports). There were many more projects of the first type and they were based on various forms of employees' voluntary activities.

\section{ORGANIZATION}

The realized projects can generally be divided into the following forms:

1) grant projects - without the active and direct participation of employees (an organization supports beneficiaries financially). Employees may participate indirectly (e.g. by indicating beneficiaries, deducting $1 \%$ of income tax);

2) employees' voluntary activities - with the active and direct participation of employees, including:

a) team (group) projects - employees find an entity, prepare assumptions of a project and realize the same and the employer supports the project financially;

b) individual projects - employees may use a specified time during a year for voluntary activities during working hours. The employer does not provide any financial support; 
c) competence-related - employees conduct educational classes.

Voluntary activities are nearly always done during working hours and employees are not additionally paid for these. Only 1 of the organizations formalized the voluntary activities (specific regulations, etc.).

Solutions developed in the organizations were often reproduced and became part of their cultures. In one case, an organization supported the projects, which were realized outside the organization and in which employees were involved.

\section{INNER INITIATIVE}

Initiators may include employees or executive staff and activities are most often initiated by employees ( 4 organizations) and in 3 cases by executive staff. If employees are not initiators, an organization makes an effort to include them in a project. Some projects result from an employee's situation (e.g. a sick family member, or a campaign for the school to which an employee's child goes).

\section{MOTIVATING}

The organizations motivate their employees mainly through information campaigns (posters, displays, intranet, mailing) as well as:

- meetings with employees organized by the executive staff or voluntary workers who share their experience;

- awarding the most active voluntary workers (including with material/financial awards, distinction, an additional day off);

- organizational support of employees (e.g. covering by insurance, ensuring of transport/boarding);

- events (e.g. CSR days, week/gala of volunteering);

- integration tips, activating games.

In one case an organization applied negative motivation by selecting employees to participate in the project.

\section{DEVELOPMENT OF COMPETENCES}

Around $1 / 3$ of the organizations admitted that it tried to develop the employees' competences necessary for participation in the projects mainly through training (e.g. related to contacts with sick children, conducting of educational classes). Most of the organizations did not conduct such activities or tried to support employees on an ongoing basis, if a given employee notified the organization of his/her needs. Most of the organizations indicated that both soft and hard competences are acquired by employees as a direct result of the realized project. 


\section{Conclusions}

This paper described the SD activities undertaken by organizations located in Poland. It partially fills the gap in the literature on the subject as regards the types of activities most often undertaken and the question of their realization - whether independently or in cooperation with others as well as whether employees take an active part in such activities, how they are motivated and what advantages and negative aspects of projects are perceived by the organizations.

In general, the analysed organizations implemented mainly social, but also ecological projects. Through the implementation of projects, they cooperated mainly with NGO-partners, but only if it was necessary (e.g. if the NGO had more knowledge and experience in a specific field). Most of the projects were based on the active participation of employees in the form of volunteering; such projects had the most positive effects for the project's goals, but also for the employees and the company. Hence, companies willingly motivated employees to participate in such projects not only through informational and organizational support, but also through various methods of distinguishing employees (e.g. volunteering gala, cup of coffee with the $\mathrm{CEO}$ ). Companies see considerable benefits in such projects for themselves and for the staff. The perceived disadvantages are few, and in any case they can be minimized and are fully discounted by the potential benefits.

It must be mentioned that the presented data are rather general and burdened by some restrictions. First, they are derived from qualitative research. In addition, the sample was selected arbitrarily and is small (13 organizations). This makes it impossible to generalize the results to entire population. Furthermore, the form of presentation is mainly descriptive and laconic (mainly because of the restrictive character limit). This may make it difficult to judge reality and compare results. Considering the above-mentioned drawbacks, it should be emphasized that this paper nonetheless makes a valuable contribution to further in-depth analysis and discussions.

\section{References}

Brundtland, G.H. (1987). Report of the World Commission on Environment and Development: Our Common Future. Retrieved from: http://www.un-documents.net/our-common-future.pdf [access: 04.04.2017]. DOI: https://doi.org/10.1080/00139157.1987.9928891.

Carter, C.R., \& Rogers, D.S. (2008). A framework of sustainable supply chain management: moving towards new theory. International Journal of Physical Distribution and Logistics Management, 38(5). DOI: https://doi.org/10.1108/09600030810882816.

Christian, M.S., Garza, A.S., \& Slaughter, J.E. (2011). Work engagement: A quantitative review and test of its relations with task and contextual performance. Personnel Psychology, 64.

DOI: 10.1111/j.1744-6570.2010.01203.x.

Cirnu, C.E., \& Kuralt, B. (2013). The impact of employees' personal values on their attitudes toward sustainable development: cases of Slovenia and Romania. Management: Journal of Contemporary Management Issues, 18(2). 
Florida, R. (1996). Lean and green: The move to environmentally conscious manufacturing. California Management Review, 39(1). DOI: https://doi.org/10.2307/41165877.

Galpin, T., Whittington, J.L., \& Bell G. (2015). Is your sustainability strategy sustainable? Creating a culture of sustainability. Corporate Governance, 15(1). DOI: https://doi.org/10.1108/CG-01-2013-0004.

Godkin, L. (2015). Mid-management, employee engagement, and the generation of reliable sustainable corporate social responsibility. Journal of Business Ethics, 130(1).

DOI: https://doi.org/10.1007/s10551-014-2149-0.

Ji, L., Huang, J., Liuc, Z., Zhua, H., \& Caia, Z. (2012). The effects of employee training on the relationship between environmental attitude and firms' performance in sustainable development. The International Journal of Human Resource Management, 23(14).

DOI: https://doi.org/10.1080/09585192.2011.637072.

Kumar, D., \& Rahman, Z. (2015). Sustainability adoption through buyer supplier relationship across supply chain: A literature review and conceptual framework. International Strategic Management Review, 3(1-2). DOI: https://doi.org/10.1016/j.ism.2015.04.002.

Liu, Z, Li J., Zhu, H., Cai, Z., \& Wang, L. (2014). Chinese firms' sustainable development - the role of future orientation, environmental commitment, and employee training. Asia Pacific Journal of Management, 31. DOI: 10.1007/s10490-012-9291-y.

Polman, P., \& Bhattacharya, C. (2016). Engaging employees to create a sustainable business. Stanford Social Innovation Review, Fall.

Seuring, S., \& Müller, M. (2008). From a literature review to a conceptual framework for sustainable supply chain management. Journal of Cleaner Production, 1.

DOI: https://doi.org/10.1016/j.jclepro.2008.04.020.

Szołtysek, J. (2009). Logistyka zwrotna. Poznań: Instytut Logistyki i Magazynowania.

Temminck, E., Mearns, K., \& Fruhen, L. (2015). Motivating employees towards sustainable behaviour. Business Strategy and the Environment, 24(6). DOI: https://doi.org/10.1002/bse.1827.

Verhulst, E., \& Boks, C. (2014). Employee empowerment for sustainable design. The Journal of Corporate Citizenship, 55. DOI: https://doi.org/10.9774/GLEAF.4700.2014.se.00008.

Wolf, J. (2013). Improving the sustainable development of firms: The role of employees. Business Strategy and the Environment, 22(2). DOI: https://doi.org/10.1002/bse.1731.

Wu, Z., \& Pagell, M. (2011). Balancing priorities: Decision-making in sustainable supply chain management. Journal of Operations Management, 29(6). DOI: https://doi.org/ 10.1016/j.jom.2010.10.001. 